Matthew Burkes is an ST1 doctor in General Practice Specialist Training. He lives with his wife and two children in Chichester, West Sussex. He publishes on his last day of GP placement, so he's happy!

mattburkes@doctors.net.uk

Mike Fitzpatrick

fitz@easynet.co.uk

Marinus Klijnsma is a consultant

psychiatrist in Essex.

marinus.klijnsma@nemhpt.nhs.uk

\section{Helen Lester}

Helen.Lester@manchester.ac.uk

John Middleton has now worn out two dogs by running with them in the mornings. He is not planning on getting another. However, he is planning to develop his career as a playwright and opera composer - that is if he gets time off from gardening. Copies of his dad's book are available to anyone who sends a stamped addressed C5 envelope. For details contact:

john@thebrinks.wanadoo.co.uk

Jane Moore is a part-time GP and has just completed a Masters degree in the Medical Humanities. The 12 years that she spent working in sub-Saharan Africa have left her with a great appreciation of the quality of the provision of medical care in the UK and an awareness of the importance of good medical education. moore.jane@doctors.org.uk

Don O'Mahony is a GP in Port St Johns, South Africa. Don is an abbreviation of Donnchadha, the Irish version of Denis. donomahony@gmail.com

Bassem Saab is a programme director in the department of family medicine at the American University of Beirut

brsaab@aub.edu.lb

Kate Salmon works as a GP in a rural general practice in North Essex. kate.salmon1@yahoo.co.uk

John Temple is a lecturer in general practice at Nottingham University Medical School

John.Temple@nottingham.ac.uk

Competition!!

For readers. Mid-winter, bereft of proper Test Cricket to fill gaps between patients, there is always ocean yacht racing. Two round the world races in progress at the moment, the Volvo Ocean Race, and the Vendee Globe (http://www.vendeeglobe. org/en/). The former is glitzy and

watchable but mainly about selling Sports Utility Vehicles. No longer fashionable, in any sense. The Vendee Globe is different. One person, one very big terrifyingly fast yacht, start Les Sables d'Olonne in

Brittany, finish there, no stops in between.

Down the Atlantic, turn left at Cap de

Bonne Esperance, then Southern Ocean

for 10000 nautical miles, screaming along, avoiding ice, till Cap Horn, then another

left, and home. Definitively French. Pure and awesome. Which competitors would make good GPs?

Alec Logan

aleclogan@dial.pipex.com
'This happened on December 30th 2003' she began, the American drawl initially disconcerting from such a very British icon. 'That may seem a while ago but it won't when it happens to you. And it will happen to you. The details will be different, but it will happen to you. That's what I'm here to tell you.'

Although l'll own that a play about losing your spouse and daughter is not the obvious choice for a wedding anniversary treat, the opportunity to see Vanessa Redgrave as Joan Didion in The Year of Magical Thinking this Autumn was too rare to pass up. So we listened as she quietly raged against the injustice of her husband's sudden death, her grief creating a type of magical thinking that meant she had to keep his shoes and clothes for his return. I was reminded, as we sat there, spellbound in the stalls, of Robert Klitzman's reflections on some doctors' own version of magical thinking. ${ }^{1}$ Klitzman suggests, among other things, that through our professional training and the socialisation that forms an intrinsic part of medical rites of passage, some of us somehow come to see our metaphorical white coats as protective against illness and death. We perhaps feel magically invulnerable to disease. He cites numerous stories of magical thinking including a sick doctor admitted to an ICU who looked up her symptoms dispassionately on a personal laptop and considered writing herself up as a case report. It also helped me make sense of a particular incident a few years ago when I refused to get on the porter's trolley but insisted instead on taking my black pointy boots out of the patient locker to clip clop along the corridor I usually walked as a local GP. Surely if I had my trusty work boots on, I could be on my way to the right sort of theatre? I wonder if that's why the Obituaries are one of the most read sections in the BMJ? Do we sit there silently wondering how such and such a doctor could possibly have contracted this or that illness, or died before their three score years and ten?

So perhaps we are programmed, more than most, to think that we are invincible will never get ill, never grow old, never need to find sheltered accommodation, or, God forbid, a nursing home. Does our predisposition for magical thinking alter the way we think about old age and therefore older people? I'm not sure, but it may be worth a little evidence-based reflection.

We know that by 2011 the mean age of the UK population will have exceeded 40 years for the first time in history. Over the next 25 years, the number of people over 65 years will increase by $60 \%$, from 9.6 million to 15 million, and account for $20 \%$ of the total population. ${ }^{2}$ Currently, about $5 \%$ of older people (480 000 UK citizens) live in residential homes ${ }^{3}$ and $23 \%$ of calls to an abuse help line are made from residential care homes. ${ }^{4}$ Is this our problem? Should we all engage more actively with the issues? Or do we feel protected in some sense by our magical white coats, our reduced ability to perceive death and old age as something personal? Indeed, I wonder if the Let's Respect Campaign, ${ }^{5}$ which highlights the principles of best practice in the care of older people with mental health needs, would be as powerful without the promotional memory box. Open the box and you are greeted with haunting photographs of older people clutching pictures of their younger selves or of a long dead khaki-clad husband. The emotional images pierce our magical white coats and remind us all who we are and who we will become.

Perhaps next time I visit our local nursing home I won't try and get back into my car quite as quickly. Perhaps I will spend longer talking about the photograph on the shelf, asking about feelings not symptoms. Perhaps I will remember Joan Didion's words that although the details will be different, it will happen to me.

\section{REFERENCES}

1. Klitzman R. When doctors become patients. Oxford: OUP, 2008.

2. Help the aged. Demographic statistics.

http://www.helptheaged.org.uk/NR/rdonlyres/972B 5831-4587-4EB6-A1E0-

D3E15A8CEFF6/0/demographicfactsheet.pdf (accessed 27 Nov 2008)

3. House of Lords House of Commons. Joint Committee on Human Rights. The human rights of older people in healthcare. Eighteenth Report of Session 2006-7. London: The Stationery Office, 2007.

4. Action on Elder Abuse. Hidden voices: older people's experience of abuse. London: Astral House, 2004.

5. Department of health. Older people's mental health. Let's respect.

http://www.olderpeoplesmentalhealth.csip.org.uk/le ts-respect.html (accessed 27 Nov 2008).

DOI: 10.3399/bjgp09X394987 